\title{
Pelatihan Penerapan Model Course Review Horay (CRH) Dalam Pembelajaran Matematika SMP
}

\section{Tetty Natalia Sipayung}

Universitas Katolik Santo Thomas

tetty_sipayung@ust.ac.id

\begin{abstract}
Abstrak
Dampak dari guru yang menerapkan pembelajaran satu arah adalah membuat siswa merasa bosan dan kurang merespon pembelajaran. Model Course Review Horay $(\mathrm{CRH})$ merupakan salah satu model pembelajaran yang berbentuk permainan edukatif sebagai solusi alternatif masalah tersebut. Model CRH tersebut diterapkan melalui kegiatan pengabdian masyarakat di sekolah dengan metode ceramah, permainan, dan tanya jawab. Subjek kegiatan ini adalah kelompok masyarakat yaitu guru beserta siswa kelas VII SMP HKBP Lubuk Pakam. Adapun tujuan umum kegiatan ini untuk menciptakan iklim pembelajaran yang baik dan menyenangkan di sekolah. Sedang tujuan khususnya untuk mengetahui apakah siswa memahami pembelajaran dengan menggunakan model $\mathrm{CRH}$ dan pencapaian kompetensi siswa bekerja secara tim. Dalam penerapannya, model $\mathrm{CRH}$ membutuhkan kerjasama siswa dalam kelompoknya. Setelah dilaksanakan kegiatan ini diperoleh hasil bahwa guru dan siswa mampu memahami dan melaksanakan praktik penerapan model $\mathrm{CRH}$ dengan baik. Mereka terlihat semangat dan gembira saat pembelajaran berlangsung. Terlihat usaha keras dari masing-masing kelompok siswa untuk menjawab soal-soal dengan benar dan cepat serta semangat meneriakkan yel-yel kelompoknya. Kegiatan ini menimbulkan dampak positif dalam pembelajaran di sekolah. Pada akhir pelaksanaan kegiatan ini, pihak sekolah menyatakan rasa senang dan bersyukur dengan telah dilaksanakan kegiatan pengabdian masyarakat di lingkungan sekolahnya.
\end{abstract}

Kata Kunci: course review horay, pembelajaran matematika

\section{Pendahuluan}

Tidak dapat dipungkiri bahwa tidak semua siswa menyukai matematika. Namun harus disadari bahwa matematika mempunyai peranan penting dan bermanfaat khususnya dalam bidang pendidikan. Matematika sebagai dasar berpikir dan instrument evaluasi dalam mengukur kemampuan dan keberhasilan siswa. Salah satu bukti yang meneguhkan pernyataan tersebut adalah dijadikannya matematika sebagai salah satu pelajaran yang diujikan secara nasional melalui Ujian Nasional baik di tingkat Sekolah Dasar maupun di tingkat Sekolah Menengah demikian juga dalam pelanjutan ke tingkat Perguruan Tinggi. Oleh karena itu diperlukan suatu upaya keras bagaimana supaya sebagian besar siswa menyukai matematika bahkan mengganggap matematika itu suatu pelajaran yang menarik, bukan menakutkan dan membingungkan, serta membosankan.

Permasalahan dalam pembelajaran matematika memang sangat banyak jika dianalisis secara kompleks. Penerapan kurikulum yang baru saat ini menuntut pembelajaran 
berpusat pada siswa. Untuk itu diharapkan guru mampu memilih dan mendesain serta menerapkan pembelajaran yang menjadikan siswa dapat mengembangkan potensi yang tersimpan dalam dirinya.

Sebenarnya banyak model pembelajaran yang dapat diterapkan. Salah satunya adalah model pembelajaran Course Review Horay (CRH). Model pembelajaran $\mathrm{CRH}$ merupakan salah satu model pembelajaran metode kooperatif dengan cara mengelompokkan siswa ke dalam kelompok-kelompok kecil, berbentuk permainan dengan menggunakan kotak diisi nomor soal dan siswa diharapkan dapat mengerjakan soal sesuai dengan nomor yang ada dalam kotak tersebut.

Berdasarkan hasil penelitian, model $\mathrm{CRH}$ dapat meningkatkan kemampuan pemahaman konsep siswa (Salim, 2019; Elis, 2019; Maryam, dkk., 2016; Rangkuti, 2019), dapat meningkatkan sikap ilmiah siswa (Darmawati, dkk., 2011; Rosmaini, dkk., 2012), dapat meningkatkan motivasi siswa (Sari, dkk., 2016), dapat meningkatkan keaktifan siswa (Julia, dkk., 2018; Aisyah, 2019; Djoko, 2020; Kusfabianto, dkk., 2019; Nurhang, 2019), dapat meningkatkan aktivitas siwa (Laksana, 2017; Hasanah, dkk., 2020; Agustiningrum, 2017; Fauzi, dkk., 2019; Daulay, 2018; Metroyadi, 2019; Lestari, dkk., 2016), dan meningkatkan hasil belajar siswa (Dewi \& Ni Wayan Arini, 2018; Lapatta, 2019; Ahmadi, 2018; Rakhmawati, 2019; Asih, 2018; Putra, 2012; Tulaseket, 2018).

Menyadari akan manfaat model pembelajaran $\mathrm{CRH}$, maka perlu diadakan pelatihan penerapan model $\mathrm{CRH}$. Pelatihan penerapan model ini merupakan bagian dari kegiatan pengabdian pada masyarakat. Kegiatan pengadian pada masyarakat dapat digunakan sebagai teknik atau kegiatan dalam menengimplementasikan produk penelitian. Kegiatan pengabdian pada masyarakat merupakan salah satu tugas dosen di perguruan tinggi yang merupakan bagian dari Tri Darma Perguruan Tinggi dalam menyebarkan ilmu pengetahuan yang dimilikinya kepada masyarakat.

Kegiatan pengabdian pada masyarakat dilakukan dalam bentuk ceramah, permainan, dan tanya jawab dan ditujukan secara khusus pada siswa kelas VII SMP HKBP Lubuk Pakam. Program ini diharapkan juga memberikan kontribusi positif bagi Universitas Katolik Santo Thomas dengan masyarakat di lingkungan sekolah. Tujuan kegiatan pengabdian pada masyarakat ini adalah sebagai berikut: (1) untuk mengetahui apakah siswa-siswa kelas VII SMP HKBP Lubuk Pakam memahami model CRH dalam pembelajaran matematika; (2) untuk mengetahui pencapaian kompetensi siswa bekerja secara tim pada pembelajaran matematika dengan menerapkan model $\mathrm{CRH}$.

\section{Metode Pelaksanaan}

Bentuk kegiatan pengabdian pada masyarakat ini yaitu ceramah, permainan, dan tanya jawab. Mitra kegiatan ini adalah SMP HKBP Lubuk Pakam. Sekolah tersebut terletak di Jl. Tuanku Imam Bonjol No.14 Lubuk Pakam. Subjek pengabdian yaitu siswa kelas VII SMP yang berjumlah 48 orang. Dalam pelaksanaan kegiatan ini, mereka didampingi dengan guru matematika yang bertindak sebagai pengamat ketika pembelajaran berlangsung.

Metode kegiatan dalam pengabdian pada masyarakat ini dilakukan dengan tahapan sebagai berikut: 
- Pengenalan tentang model Course Review Horay (CRH)

- Pemberian makalah

- Pelatihan penerapan model CRH

- Diskusi tanya-jawab antara peserta dengan pelatih.

\section{Pengenalan Model Course Review Horay (CRH)}

Pada tahapan ini, ketua pengabdi (pelatih) menyapa peserta kegiatan yang meliputi sekelompok siswa dan guru. Ketua pengabdi berkenalan dengan semua peserta. Setelah itu ketua pengabdi menjelaskan model Course Review Horay secara teoritis kepada para peserta. Adapun penjelasan yang disampaikan ketua pengabdi adalah sebagai berikut:

"Model pembelajaran Course Review Horay (CRH) merupakan salah satu model pembelajaran kooperatif dengan cara mengelompokkan siswa ke dalam kelompokkelompok kecil. Model pembelajaran Course Review Horay $(\mathrm{CRH})$ adalah salah satu pembelajaran dengan permainan yang menggunakan kotak diisi nomor soal dan siswa mengerjakan soal sesuai dengan nomor yang ada dalam kotak tersebut. Soal yang diberikan dapat berupa soal yang bersifat pemecahan masalah. Siswa yang terlebih dahulu menjawab benar dengan membentuk arah horizontal, vertikal atau diagonal langsung berteriak "horay" atau yel-yel lainnya. Pada pembelajaran Course Review Horay $(\mathrm{CRH})$ aktivitas lebih berpusat pada siswa, guru bertindak sebagai penyampai informasi, fasilitator dan pembimbing."

\section{Pemberian Makalah}

Sebelum diterapkan model $\mathrm{CRH}$, pelatih memberikan makalahnya kepada guru untuk dipedomani pelaksanaan pelatihan yang telah disusun pengabdi.

\section{Pelatihan Penerapan Model CRH}

1. Pelatih menyampaikan materi pelajaran matematika yang berhubungan dengan pertanyaan yang akan diberikan nantinya. Mengenal dan membandingkan bilangan bulat adalah materi yang dijelaskan oleh ketua pengabdi.

2. Setelah materi selesai dijelaskan, dilanjutkan dengan membagi siswa atas tujuh kelompok dengan masing-masing kelompok terdiri atas 6-7 orang.

3. Pelatih memberi waktu kepada masing-masing kelompok untuk mendiskusikan yelyel jika jawaban benar.

4. Pelatih memberi 7 lembar kertas yang dalam sudah dibuat 9 kotak dan ditandai dengan nomor soal $1 \mathrm{sd}$. 9 sebagai tempat menuliskan jawaban atas setiap soal yang dibacakan oleh pelatih.

5. Pelatih membacakan soal pemecahan masalah secara acak dan siswa mendiskusikan jawabannya di kelompoknya masing-masing, kemudian perwakilan siswa menuliskan jawabannya pada kotak yang nomornya disebutkan pelatih.

6. Setelah selesai beberapa soal dibacakan dan dijawab oleh siswa, pelatih mendiskusikan soal-soal yang telah diberikan. 
7. Bagi soal yang dijawab dengan benar, siswa memberi tanda check list $(\checkmark)$ dan langsung teriak "hore" atau mengucapkan yel-yel kelompoknya.

8. Pelatih menanyakan masing-masing kelompok yang menjawab benar dengan membentuk arah horizontal, vertikal atau diagonal.

9. Pelatih mempersilahkan kelompok yang menang (kelompok yang terlebih dahulu menjawab benar dengan membentuk arah horizontal, vertikal, atau diagonal) untuk langsung berteriak "hore" atau mengucapkan yel-yel kelompoknya.

10. Pelatih memanggil kelompok yang menang untuk berdiri di depan kelas.

11. Pelatih menyalami semua anggota kelompok yang menang sambil mengucapkan selamat.

Kegiatan pembelajaran dengan model $\mathrm{CRH}$ yang terdokumentasi dapat dilihat pada gambar berikut:
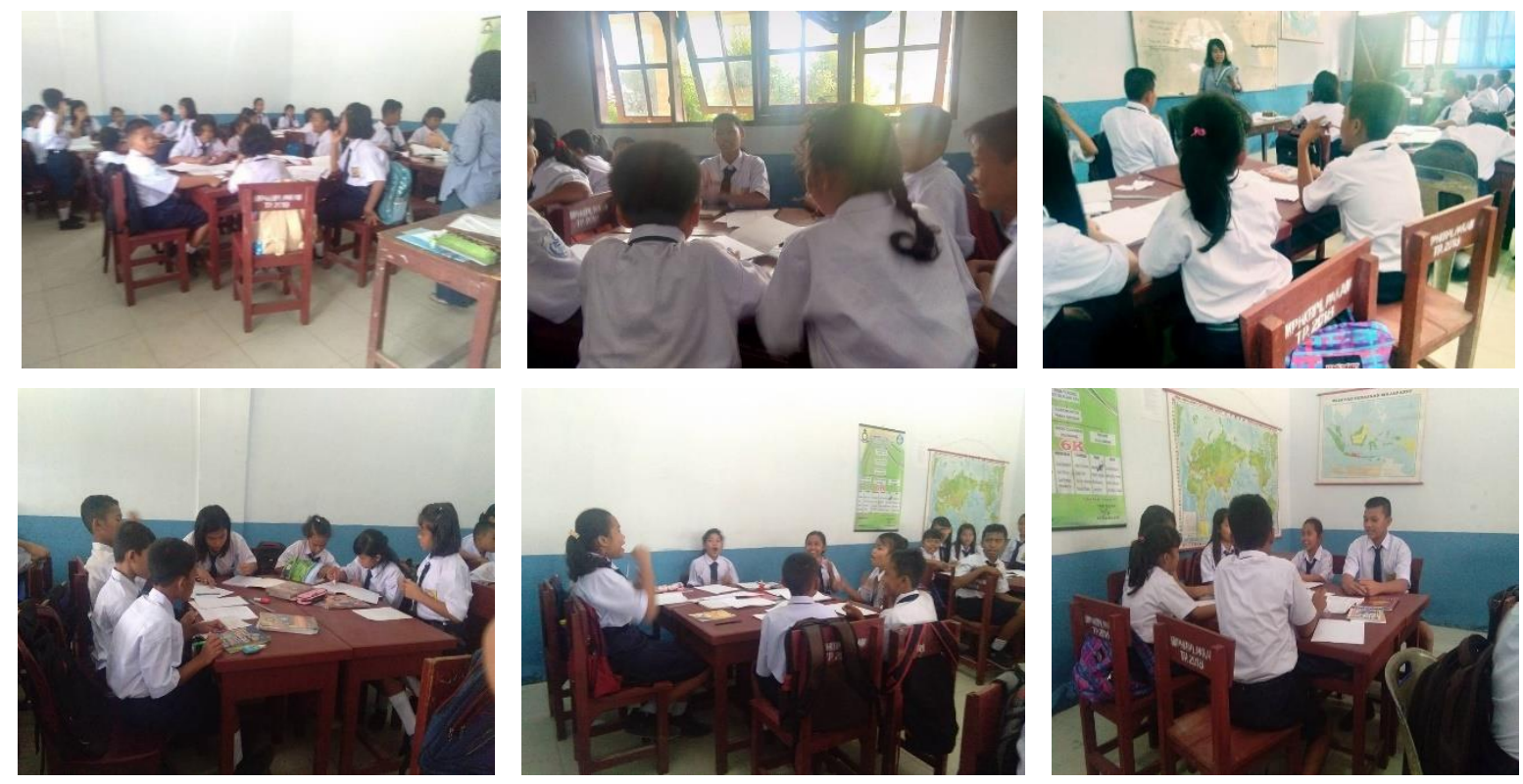

Gambar 1. Kegiatan Dalam Penerapan Model Pembelajaran CRH

Berdasarkan gambar di atas, terlihat suasana pembelajaran yang kondusif dan tampak siswa menyimak dengan baik, semangat dan berupaya dalam menyelesaikan soal-soal yang diberikan pelatih dan merasa bahagia ketika mengucapkan yel-yel kelompoknya. Kegiatan pembelajaran dengan menerapkan model CRH berjalan dengan baik dan tercapai kompetensi yang diharapkan oleh pelatih.

\section{Diskusi Tanya Jawab Antara Peserta Dengan Pelatih}

Setelah pembelajaran model $\mathrm{CRH}$ diterapkan, pelatih mengadakan diskusi tanya jawab dengan peserta (guru dan siswa). Pelatih meminta komentar peserta kegiatan atas model $\mathrm{CRH}$ yang sudah dilaksanakan. 


\section{Hasil dan Pembahasan}

Kegiatan pelatihan yang telah dilakukan memperoleh hasil, sebagai berikut:

1. Model $\mathrm{CRH}$ ini merupakan model pembelajaran dalam bentuk permainan edukatif yang dapat diterapkan khususnya dalam pembelajaran matematika untuk menigkatkan pemahaman siswa akan materi yang sudah dipelajari. Tahapan pembelajaran dengan model $\mathrm{CRH}$ adalah dengan dimulai pelatih menyampaikan materi pelajaran. Kemudian dilanjutkan siswa dibagi atas 7 kelompok. Masing-masing kelompok diberi waktu mendiskusikan yel-yel jika jawaban benar. Semua anggota kelompok wajib menyuarakan yel-yel yang sudah disepakati oleh masing-masing kelompok. Pelatih memberikan 7 lembar kertas yang telah dibuat 9 kotak yang sudah dinomori dengan angka $1 \mathrm{sd}$. 9 pada setiap tepi kotak. Setelah itu guru membacakan soal secara acak dan siswa menuliskan jawabannya pada kotak sesuai dengan nomor yang diberitahu oleh pelatih. Dalam hal ini pelatih hanya mempersiapkan 7 soal pemecahan masalah namun ketujuh nomor soal tersebut disengaja berada ada pada posisi vertical, horizontal, dan diagonal.

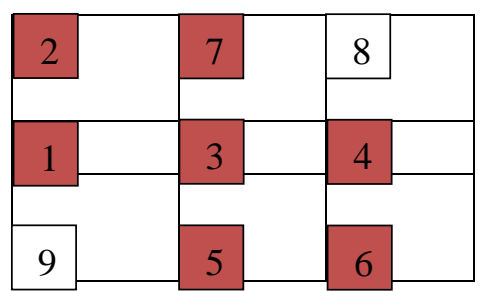

\section{Keterangan:}

1, 2, 3, 4, 5, 6, 7 adalah nomor soal yang dibacakan pelatih untuk diselesaikan

Soal nomor 2 yang pertama dibacakan pelatih dan siswa menuliskan penyelesaiannya di kotak nomor 2. Kemudian pelatih melanjutkan membaca soal nomor 4 dan siswa menuliskan penyelesaiannya di kotak nomor 4. Urutan soal yang dibacakan berikutnya adalah soal nomor 5, 1, 3, 7, dan 6. Siswa pun mendiskusikan jawaban-jawaban dari soal yang sudah dibacakan pelatih dalam kelompoknya dan perwakilan siswa diharapkan menuliskan jawabannya di kotak sesuai dengan nomor soal yang disebutkan. Setelah pelatih mendiskusikan soal-soal tersebut dengan semua kelompok siswa. Setelah diketahui jawaban atas soal-soal yang ada, maka masing-masing kelompok memberi check list $(\checkmark)$ atas jawaban yang benar dan langsung teriak "hore" atau mengucapkan yel-yel kelompoknya. Kelompok yang terlebih dahulu atau banyak menjawab benar dengan membentuk arah horizontal, vertikal, atau diagonal adalah kelompok yang menang dan dipersilahkan untuk langsung berteriak "hore" atau mengucapkan yel-yel kelompoknya. Pelatih memanggil kelompok yang menang untuk berdiri di depan kelas. Pelatih menyalami semua anggota kelompok yang menang sambil mengucapkan selamat. Kelompok yang menang dapat dilihat pada gambar berikut: 


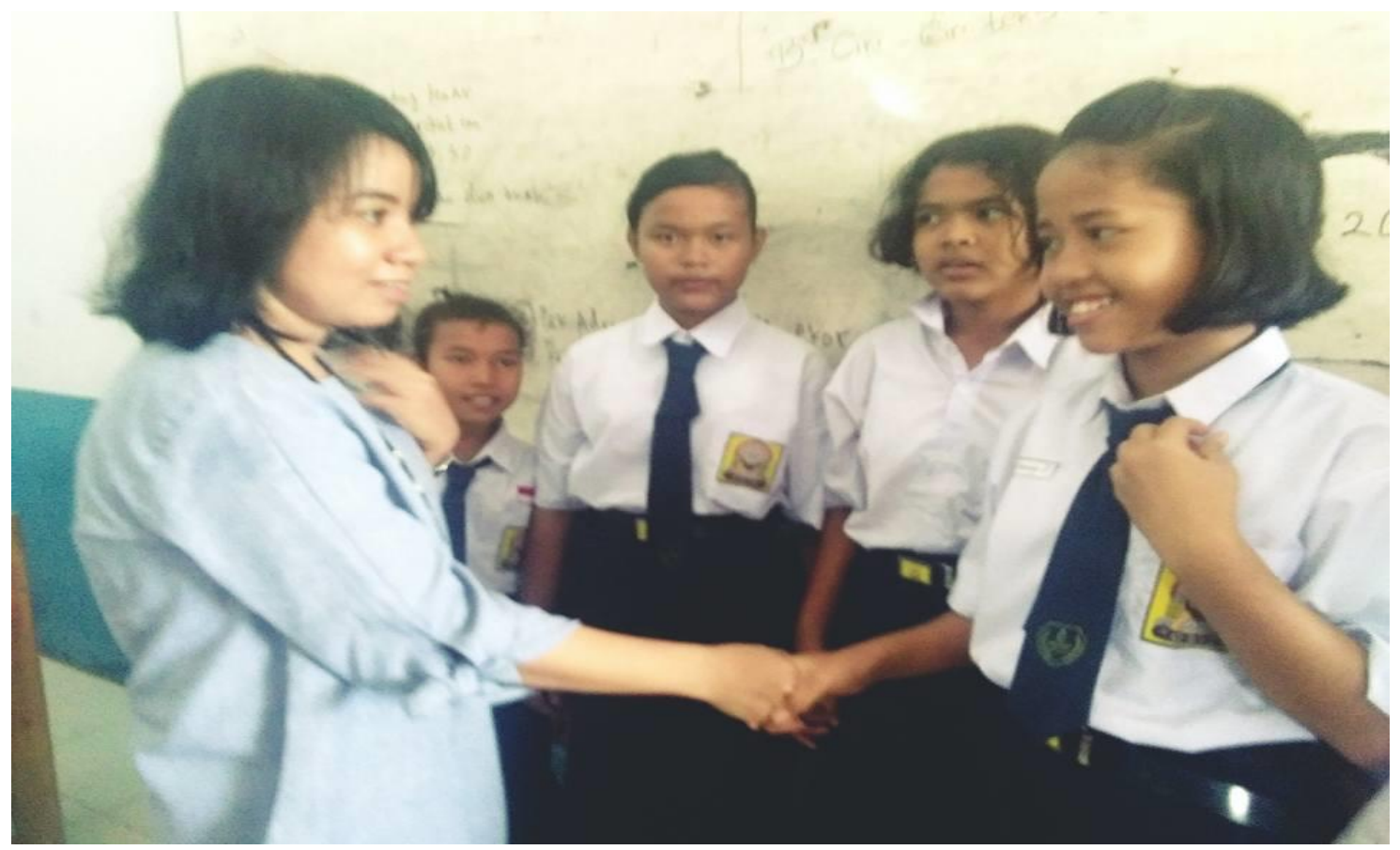

Gambar 2. Pelatih Menyalami Anggota Kelompok yang Menang

Dengan adanya model $\mathrm{CRH}$ ini selain dapat meningkatkan kemampuan menyelesaikan soal-soal matematika, siswa juga dapat belajar sambil bermain. Seluruh siswa dan guru mampu memahami dan melaksanakan praktik penerapan model $\mathrm{CRH}$ dengan baik.

2. Siswa terlihat semangat dan berusaha berama kelompoknya menjawab soal-soal dengan benar dan cepat, termasuk semangat dalam meneriakan yel-yel kelompoknya saat mereka tahu jawaban mereka benar. Kompetensi siswa bekerja secara tim merupakan pencapaian yang baik. Hal dapat diketahui dari persentase jumlah jawaban masing-masing kelompok yang benar dimana dari 7 soal yang diberikan. Diperoleh data kelompok 1, 3, 5, dan 6 masing masing menjawab 4 soal dengan benar, kelompok 2 menjawab 5 soal dengan benar, kelompok 4 menjawab 2 soal dengan benar, dan kelompok 7 menjawab 3 soal yang benar.

\section{Pembahasan}

Pelaksanaan model pembelajaran $\mathrm{CRH}$ yang diterapkan berlangsung dengan baik. Namun dalam tahap persiapan dan proses pelaksanaannya sampai selesai, ada beberapa faktor penghambat dalam kegiatan, yaitu:

1. Penyesuaian materi dan waktu antara pelaksana dengan guru matematika kelas VII SMP ketika mengajar di kelas VII SMP HKBP Lubuk Pakam.

2. Kurangnya pengetahuan siswa akan pemahaman terhadap materi matematika dan latihan membahas soal-soal matematika sehingga siswa beberapa soal matematika yang ditanya pelatih saat penerapan model $\mathrm{CRH}$ tidak bisa dijawab dengan benar.

3. Jumlah siswa yang terlalu banyak menyebabkan pembelajaran kurang terkontrol dengan baik, terutama saat mendiskusikan yel-yel untuk jawaban yang salah dan jawaban yang benar. 
Kegiatan ini berdampak positif baik bagi siswa, guru, maupun sekolah. Tidak hanya dari kemampuan pemecahan masalah siswa yang menunjukkan hasil yang baik, namun juga respon siswa juga positif atas pembelajaran yang sudah diterapkan. Siswa dilatih untuk bekerja sama dalam kelompoknya untuk menyelesaikan masalah dan saling mendukung. Dampak kegiatan ini juga dialami oleh guru. Guru menyadari bahwa model pembelajaran $\mathrm{CRH}$ merupakan salah satu alternatif yang baik untuk diterapkan dalam pembelajaran matematika. Beliau juga menyadari bahwa masih sedikit model pembelajaran yang beliau tahu dan yang sudah diterapkan. Dengan adanya kegiatan ini, bertambahlah pengetahuannya akan model pembelajaran khususnya model pembelajaran kooperatif. Kepala sekolah yang mewakili sekolah juga menilai kegiatan pengabdian masyarakat yang telah dilakukan memiliki dampak yang positif dalam meningkatkan kualitas pembelajaran di sekolah. Beliau mendukung kegiatan pengabdian masyarakat dilaksanakan di sekolahnya.

\section{Kesimpulan}

Kelompok siswa dan guru yang merupakan subjek pengabdian paham atas model $\mathrm{CRH}$ yang sudah diterapkan dalam pembelajaran matematika. Selain itu kompetensi siswa bekerja secara tim pada pembelajaran matematika adalah baik.

\section{Ucapan Terimakasih}

Penulis mengucapkan terimakasih kepada Lembaga Penelitian dan Pengabdian pada Masyarakat (LPPM) Universitas Katolik Santo Thomas yang telah memberi dukungan baik secara moril dan pembiayaan sehingga kegiatan pengabdian masyarakat ini yang merupakan bagian dari Tri Dharma Perguruan Tinggi dari awal hingga akhirnya terlaksana dengan baik. Hasil dari kegiatannya juga dapat dipublikasikan pada tulisan ini.

\section{Referensi}

Agustiningrum, A. (2017). Penerapan Model Pembelajaran Flipped Classroom dan Course Review Horay Berbasis Lesson Study Untuk Meningkatkan Aktivitas dan Hasil Belajar Siswa Pada Mata Pelajaran Ekonomi di Kelas XI IPS 2 MAN Kota Batu. Jurnal Pendidikan Ekonomi, 10(2), 111-120. https://doi.org/10.17977/UMo14V10i22017p111

Ahmadi, Y. (2018). Penerapan Model Pembelajaran Kooperatif Tipe Course Review Horay Terhadap Hasil Belajar Pada Mata Pelajaran Administrasi Umum Siswa Kelas X OTKP. Jurnal Pendidikan Administrasi Perkantoran, 6(1), 93 - 97.

Aisyah, (2019). Pengaruh Penerapan Model Pembelajaran Kooperatif Tipe Course Review Horay (CRH) Terhadap Keaktifan Belajar dan Hasil Belajar Ekonomi (Studi Pada Siswa Kelas XI MIPA SMA Negeri 3 Purwokerto). Soedirman Economics Education Journa, 1(1), 1 - 17.

Asih, R. Y. (2018). Keefektifan Model Pembelajaran Course Review Horay (CRH) Berbantu Media Pop Up Terhadap Hasil Belajar Matematika Siswa Kelas V SD. Jurnal Sekolah (JS), 2(2), 52-59.

Darmawati, dkk. (2011). Penerapan Model Pembelajaran Kooperatif Tipe Course Review Horay $(\mathrm{CRH})$ Untuk Meningkatkan Sikap Ilmiah dan Hasil Belajar Biologi Siswa 
Kelas VIII.1 SMP Negeri 2 Pekan Baru Tahun Pelajaran 2011/2012. Jurnal Biogenesis, 8(1), 41-53.

Daulay, Y. A. (2018). Penerapan Pembelajaran CRH (Course Review Horay) Untuk Meningkatkan Hasil Belajar dan Aktivitas Siswa Pada Pokok Bahasan Aritmetika Sosial di Kelas VII SMP PAB 8 Sampali T.P 2017/2018. Skripsi. FKIP: Universitas Muhammadiyah Sumatera Utara. (Tidak diterbitkan).

Dewi, A. A. I. D. P. \& Ni Wayan Arini. (2018). Penerapan Model Pembelajaran Kooperatif Tipe Course Review Horay Berbantuan Media Visual Untuk Meningkatkan Hasil Belajar IPA. Jurnal Ilmiah Pendidikan Profesi Guru, 1(1), 1-9.

Djoko, S. (2020). Penerapan Model Cooperative Learning Tipe Course Review Horay (CRH) Untuk Meningkatkan Hasil Belajar dan Keaktifan Belajar Mahasiswa Pendidikan Ekonomi. JUPEK: Jurnal Pendidikan dan Ekonomi, 1(1), 33-43.

Elis, K. (2019). Peningkatan Motivasi Belajar dan Pemahaman Konsep Matematika Melalui Model Pembelajaran Course Review Horay (CRH) Pada Siswa Kelas VII SMP Muhammadiyah Suruh Kecamatan Suruh Kabupaten Semarang Tahun Ajaran 2019/2020. Skripsi. Fakultas Tarbiyah dan Ilmu Keguruan: Institut Adama Islam Negeri (IAIN) Salatiga. (Tidak diterbitkan).

Fauzi, F. F., dkk. (2019). Penerapan Model Pembelajaran Course Review Horay (CRH) Untuk Meningkatkan Aktivitas dan Hasil Belajar Peserta Didik pada Mata Pelajaran Matematika di SDN 1 Gununglipung. 4th National Seminar on Guidance and Counseling (SNBK 2019) and Workshop on Pedagogical Theory and Practice (WTPP 2019). SHEs: Conference Series, 2(2), 110-115.

Hasanah, U., dkk. (2020). Penerapan Model PBL dengan Metode Course Review Horay Berbantuan Media Crossword untuk Meningkatkan Aktivitas dan Hasil Belajar Siswa. Jurnal Kiprah, 8(2), 78-83. https://doi.org/10.31629/kiprah.v8i2.2049

Julia, A., dkk. (2018). Penerapan Model Course Review Horay (CRH) Untuk Meningkatkan Keaktifan Siswa Pada Mata Pelajaran IPA di Kelas III SDN 7 Kebebu. Jurnal Pendidikan Dasar, 6(2), 66-73.

Kusfabianto, I., J., dkk. (2019). Penerapan Model Pembelajaran Course Review Horay untuk Meningkatkan Keaktifan dan Hasil Belajar Matematika Kelas IV SD. JTAM (Jurnal Teori dan Aplikasi Matematika), 3(2), 87-92.

Laksana, T. S. (2017). Penerapan Model Pembelajaran Kooperatif Tipe Course Review Horay (CRH) Berbantuan Media Lembar Kerja Siswa (LKS) Untuk Meningkatkan Aktivitas dan Hasil Belajar Siswa Pada Mata Pelajaran Ilmu Pengetahuan Sosial (IPS) di Kelas IX C SMP Negeri 1 Sukasada Tahun Ajaran 2016/2017. Jurnal Pendidikan Ekonomi Undiksha, 9(1), 12-24.

Lapatta, J. (2019). Peningkatan Hasil Belajar Siswa Melalui Penggunaan Model Course Review Horay Pada Mata Pelajaran IPA Kelas IV SD Inpres Sintuwu. Jurnal Kreatif Online, 7(3), 165-177.

Lestari, N. A. P., dkk. (2016). Implementasi Model Pembelajaran Course Review Horay Untuk Meningkatkan Aktivitas dan Hasil Belajar IPA di SD. e-journal PGSD Universitas Pendidikan Ganesha Jurusan PGSD, 4(1), 1-10.

Maryam, S., dkk. (2016). Penerapan Metode Course Review Horay (CRH) Dalam Upaya Peningkatan Kemampuan Pemahaman Matematis Siswa. Jurnal Matematika Ilmiah STKIP Muhammadiyah Kuningan, 2(2), 100-107. 
Nurhang. (2019). Penerapan Model Pembelajaran Kooperatif Tipe Course Review Horay $(\mathrm{CRH})$ Dalam Meningkatkan Aktivitas dan Hasil Belajar Biologi Peserta Didik Kelas XI MIPA.1 SMA Negeri 1 Parepare. Thesis. http://eprints.unm.ac.id/id/eprint/13549

Metroyadi. (2019). Implementasi Kombinasi Model Auditory, Intellectually, Repitition (AIR), Mind Mapping dan Course Review Horay ( $\mathrm{CRH})$ Untuk Meningkatkan Aktivitas Belajar Siswa Kelas IVA SDN Sungai Lulut 5 Kota. Prosiding Seminar Nasional PS2DMP ULM, 5(2), 77-88.

Putra, G. A. (2012). Penerapan Model Pembelajaran Course Review Horay Pada Mata Pelajaran TIK Untuk Meningkatkan Hasil Belajar Siswa Kelas X 5 SMA Negeri 2 Singaraja Tahun Ajaran 2011/2012. Kumpulan Artikel Mahasiswa Pendidikan Teknik Informatika (KARMAPATI), 1(4), 706-718.

Rakhmawati, E. D. (2019). Peningkatan Hasil Belajar dan Aktivitas Belajar Pelajaran Sosiologi Dengan Model Course Review Horay (CRH) di Kelas XI IPS 1 SMAN 1 Gebog Kudus. Ijtimaiya : Journal of Social Science Teaching, 3(1), 56-61.

Rangkuti, D. (2019). Implementasi Model Course Review Horay Untuk Meningkatkan Pemahaman Konsep Bilangan 1-10 dan Aktivitas Belajar Anak Usia Dini.

Salim, H. (2019). Prosiding Seminar Nasional \& Expo II Hasil Penelitian dan Pengabdian Masyarakat, 935-941.

Sari, N. L. K. Y, dkk. (2016). Penerapan Model CRH Berbantuan Media Visual 3D Untuk Meningkatkan Motivasi dan Pemahaman Materi IPA Siswa Kelas V SD. e-Journal PGSD Universitas Pendidikan Ganesha Jurusan PGSD, 4(1), 1-10.

S. Rosmaini, dkk. (2012). Penerapan Model Pembelajaran Kooperatif CRH (Course Review Horay) Untuk Meningkatkan Sikap Ilmiah dan Hasil Belajar Biologi Siswa Kelas XI IPA SMA Negeri 5 Pekan Baru Tahun Ajaran 2011/2012. Jurnal Biogenesis, $8(2), 43-53$.

Tulaseket, C. (2018). Penerapan Model Pembelajaran Course Review Horay Untuk Meningkatkan Hasil Belajar Siswa Materi Sistem Klasifikasi Makhluk Hidup Pada Kelas X SMA Negeri 14 Ambon. Biopendix, 4(2), 77-82. 